\title{
Problems of Payment of Compensations from the Funds for the Social Security
}

\author{
Bakhodir Sheralievich Khusanov - Associate Professor \\ Samarkand Institute of Economics and Service
}

\begin{abstract}
This article is devoted to the study of the concept of social security for its elements and types of compensation payments, social subsidies, maternal capital, and much more. The article presents and studies the opinions of scientists in the field of social security financing system. The relevance of this topic is not in doubt, since social payments are one of the key aspects of social support for the population.

Keywords: social payment, compensation, subsidy, allowances, material support, maternal capital, financial regulation of social security, privileges.

DOI: $10.7176 / \mathrm{EJBM} / 12-20-03$

Publication date:July $31^{\text {st }} 2020$

\section{Introduction}

The right to receive compensation from social security funds is developing in an evolutionary way with the gradual replenishment of the corresponding financial mechanism, moreover, this phenomenon is on an ascending line after the development of all elements of social security. In this case, we have in mind not only the improvement of the elements of the financial mechanism for regulating social security relations, but also the coverage of a large number of people in difficult situations by the industry, the increase in the volume and content of the compensatory support provided by the state [see Figure 1]. This trend should be regarded in two ways. On the one hand, this is certainly a positive phenomenon, testifying to the financial and economic potential of the state. But, on the other hand, this trend cannot but alarm, since the increase in the number of needy citizens, especially its sharp surge, indicates serious miscalculations in the financial and economic policy of the state and in the social sphere.
\end{abstract}

\section{Literature review}

So compensation is an element of social security. Domestic legislation in the context of social security does not contain a definition of compensation. In the labor legislation - the Code of the Republic of Uzbekistan - this definition is enshrined in Art. 170 of the Labor Code of the Republic of Uzbekistan, which states: "Compensation of expenses associated with work, that is, additional expenses of an employee related to the performance of his labor duties (Articles 171, 172, 173), shall be reimbursed by the employer on the terms and in the manner established by law, collective agreements and agreements as well as employment contracts". [1]

It follows that the payments established in order to reimburse employees the costs associated with the fulfillment of other duties stipulated by this Code, in our opinion, are distinguished by the complexity of distinguishing allowances and compensations. In the legal aspect of allowances and compensations, some authors identify them. [2] For example, S.S.Alieva believes that "compensation payments are close in their goals and legal nature to privileges. S.S.Alieva sees such a difference, firstly, in the allowance assigned on the basis of laws, and compensation payments - on the basis of by-laws; secondly, in the amount of privileges, which is much higher than the amount of compensation payments". [3] But one can hardly call these signs more significant, allowing them to differentiate. In addition, it is difficult to agree with the arguments given by the author, because some compensations are established by law. In the context of social protection of citizens exposed to radiation as a result of the Chernobyl disaster, several types of compensation payments are provided. However, their size does not always exceed the amount of allowances, and it is hardly appropriate to make such a comparison, since the law establishes various grounds for their provision.

S.S.Alieva also formulates the following definition of social security compensations - these are targeted property grants sent to citizens in need with the aim of assisting them in restoring their lost position on the grounds, conditions, in the amount and manner established by law. [3]

In our opinion, the current legislation does not provide a basis for considering compensation payments as inkind assistance, setting the amount of compensation in cash payments or amounts (emphasized by us).

However, based on this provision, J.R. Zaynalov proposes to consider compensation as a special financial mechanism aimed at compensation for damage caused to an individual or legal entity as a result of both legal and unlawful actions of counter-entities, expenses incurred, and neutralization of other obligations related to infringement of his interests. [4] In our opinion, this raises the principle of objections, because compensation does not take into account the specifics of socially secured relations within the framework of allowances.

S.S. Alieva believes that compensation payments have much in common with allowances. She believes that their similarity is determined by the following signs: limitation by time frame; grounds for appointment are recognized as socially significant from the point of view of the state; as part of the allowances are social support 
payments; provided for specific purposes. [3] The main difference is in the very essence of allowances and compensation payments. [4] Yes, we agree with the opinions of J.R. Zaynalov as in practice, all compensations are paid for the purpose of compensation (highlighted by us). Compensation (partial) of unearned salary during long vacations without salary caused by temporary suspension of work, or during parental leave until he reaches the age established by law or by-laws, and so on. [4]

Indeed, in the Republic of Uzbekistan allowances are paid in the amounts established by law with the aim of assisting the population.

Therefore, while also sharing the above point of view, J.R. Zaynalov [5] and S.S.Alieva [3] it is necessary to note the following: in order to compensate payments do not dissolve in the system of allowances and strengthen their status as a socially significant element social security, the legislator needs to take into account and develop the special nature of these grants as an adequate financial mechanism for restoring property status, compensating for adverse consequences corresponding to the nature of the harmful effects (e.g. compensation for Chernobyl victims) or expenses actually incurred (e.g. compensation for part of the parental fee for child support in educational institutions of preschool education), in cases recognized by the state as socially significant. It is a compensatory, restorative feature that should be clearly seen in normative legal acts. In our opinion, compensation should correspond to the value (actual or conditional) of the object for the compensation of which they are intended.

\section{Research methodology}

Comparative, statistical analysis, grouping, comparison and economic-mathematical modeling.

\section{The main part}

In modern conditions, compensation should be provided not only for social security, but also for labor characteristics (i.e. compensation for travel expenses to the place of business trip, compensation for unused labor leave, etc.), and civil law (moral compensation harm, compensation for deposits, etc.). But compensation payments in the context of social security differ from compensation provided by other branches of the law in that the condition for their purpose and payment is the onset of social risks, as well as the determination of the types and sizes of compensation payments in the legislation, and not by contract [see table 1].

It should be noted that compensation payments, as an element of social security, are provided to citizens upon the occurrence of social risks free of charge and irrevocably from the funds of budgets of different levels. Particular attention should be paid to this fundamental distinguishing feature, since the state, as noted by D.R. interests, and as the manager of the budget created and spent within the interests of society. [4] 


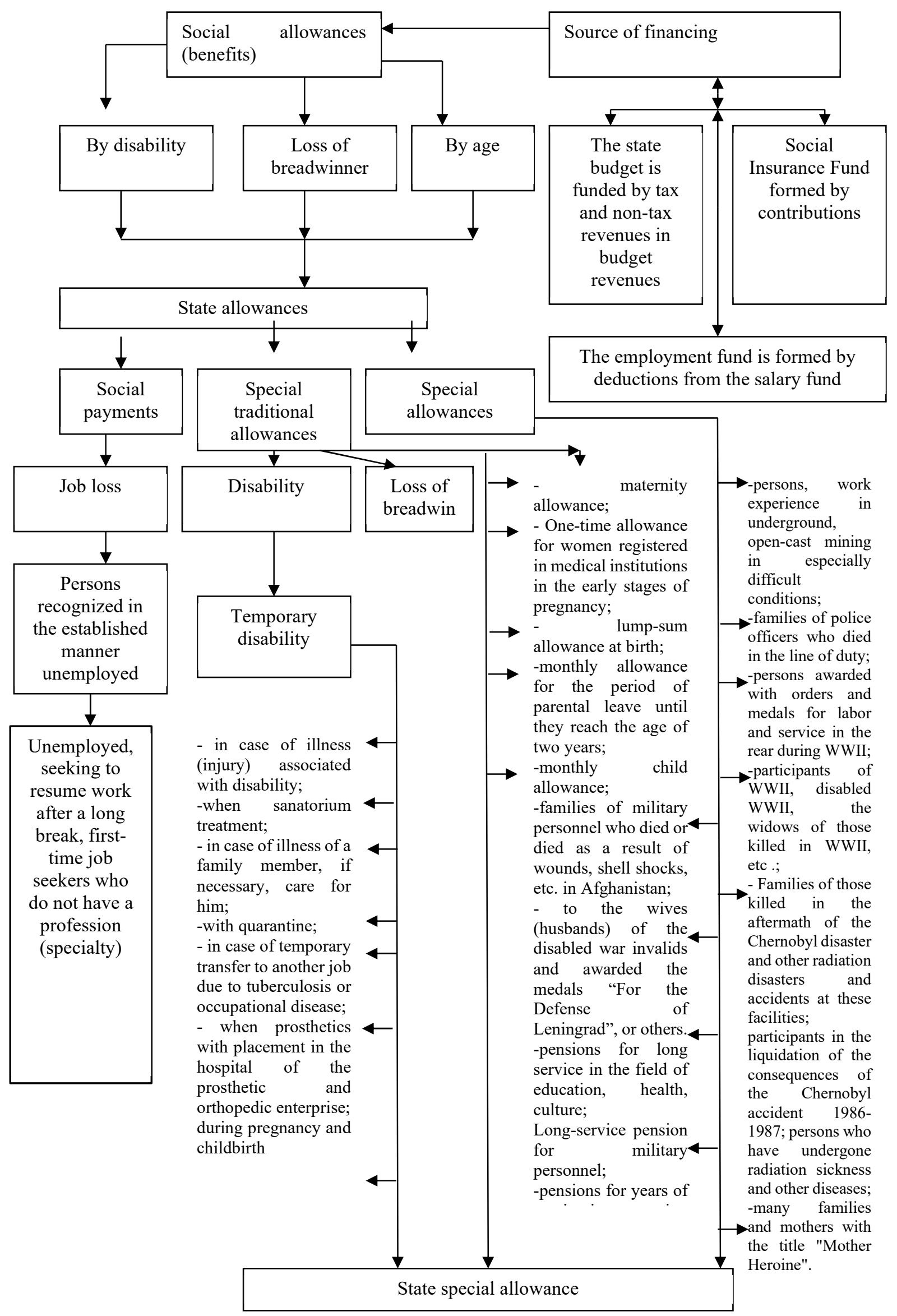

Figure 1. Types of allowances and sources of their formation 
Table 1

Social Security Components

\begin{tabular}{|c|c|c|c|c|c|}
\hline № & Forms & Types & $\begin{array}{l}\text { Sources of } \\
\text { formation }\end{array}$ & Regulations & $\begin{array}{c}\text { Social Security } \\
\text { Authorities }\end{array}$ \\
\hline 1 & $\begin{array}{l}\text { The way to meet the } \\
\text { needs provided to } \\
\text { citizens in cash: } \\
\text { A) pensions; } \\
\text { B) allowances; } \\
\text {-compensation } \\
\text { payments: } \\
\text { in kind; social services; } \\
\text { social assistance (in the } \\
\text { form of clothing, } \\
\text { household items, etc.). }\end{array}$ & $\begin{array}{l}\text {-pensions; } \\
\text {-social benefits; } \\
\text {-compensation; } \\
\text {-social services; } \\
\text {-social medical } \\
\text { care; } \\
\text {-social help; } \\
\text {-social benefits } \\
\text { and advantages }\end{array}$ & $\begin{array}{l}\text {-insurance } \\
\text { premiums; } \\
\text {-appropriations from } \\
\text { the state budget, i.e. } \\
\text { compulsory social } \\
\text { insurance funds and } \\
\text { budget funds } \\
\text { allocated for social } \\
\text { security }\end{array}$ & $\begin{array}{l}\text { Laws of the } \\
\text { Republic of } \\
\text { Uzbekistan } \\
\text { Social Security } \\
\text { Regulatory } \\
\text { Relationships } \\
\text { and By-Laws }\end{array}$ & $\begin{array}{l}\text { - bodies of } \\
\text { obligatory } \\
\text { social } \\
\text { insurance; } \\
\text {-government } \\
\text { departments; } \\
\text { - bodies of } \\
\text { local entities; } \\
\text { non- } \\
\text { governmental } \\
\text { bodies; } \\
\text { public } \\
\text { organizations }\end{array}$ \\
\hline 2 & $\begin{array}{l}\text { The way of organizing } \\
\text { social security through } \\
\text { compulsory social } \\
\text { insurance both through } \\
\text { the use of appropriations } \\
\text { from the state budget, as } \\
\text { well as through mixed } \\
\text { forms of social security }\end{array}$ & & & & \\
\hline \multicolumn{6}{|c|}{ Structures of relatively independent systems } \\
\hline 2 & $\begin{array}{l}\text { Pension system } \\
\text { Social benefits system } \\
\text { and compensation } \\
\text { payments }\end{array}$ & $\begin{array}{l}\text { 1.System of } \\
\text { social services } \\
\text { and social } \\
\text { services; } \\
\text { 2. The system of } \\
\text { social protection } \\
\text { of the health of } \\
\text { citizens; } \\
\text { 3. The system of } \\
\text { state social } \\
\text { assistance; } \\
\text { 4. The system of } \\
\text { social benefits } \\
\text { and advantages }\end{array}$ & & & \\
\hline
\end{tabular}

Thus, compensations, as an element of social security, are provided: upon the occurrence of social risks with a view to compensation; types and amounts of compensation are established by law.

Another element of social payments is subsidies. The legislative definition of subsidies is contained in the Budget Code (2013), which states that the subsidy is the intended purpose of the full or partial payment of social services provided to citizens. But this concept is not universal in nature, which is due to the framework nature of the law, and cannot be used to characterize all types of subsidies provided for by the Budget Code of the Republic of Uzbekistan, taking into account the criteria and nature of the formation of social security. In addition, this approach to the assessment of subsidies indicates both the insufficient development of a methodological approach to social security in the broad sense of the word, taking into account the particularities of consumers (recipients) of subsidies, and the limited possibilities for attracting financial resources for this purpose necessary for the creation and development of subsidy relations as part of social security.

Touching on this issue, S.S.Alieva gives the concept of subsidy as a type of state social assistance and suggests considering the subsidy as a non-cash form of settlement with the population provided in case of excess payments for housing and utilities consumed in accordance with the social norm of the housing area and norms of consumption of utilities in excess of the established level of total family income. [3]

In addition to the established attitude to subsidies, J.R. Zaynalov [4], S.S.Alieva [3], E.Khodjaev and Z.Rasulov [6] consider the subsidy as cash provided in order to pay citizens to satisfy their material wealth. Along with this, examining subsidies in the general theoretical aspect, J.R. Zaynalov questions the irrevocability and believes that "subsidies are a forced payment and are temporary. Therefore, such payments will be used in due 
time, they are refundable. [4]

The Budget Code of the Republic of Uzbekistan provides liability for the misuse of subsidies in the form of the return of all or part of the money spent for other purposes. [7] This provision, notes J.R. Zaynalov, makes it possible to single out such an important feature that distinguishes subsidies from other social payments as the targeted nature. [5] It is important not only the main purpose of the provision - the alignment of the material situation of those in need with the rest of the society, this feature is also inherent in other elements of social security. The final goal, which is fixed in the legislation, and the achievement of which is confirmed by providing the necessary documents, is of great importance. In addition, all types of subsidies are financed from budgetary funds and can be characterized as alimentary.

Therefore, in our opinion, the subsidy, as an element of social security, manifests itself in social payments and is provided free of charge from the budgets of various levels strictly for use for the purposes established by law.

In practice, a number of countries apply monthly cash payments. Similar payments appeared in the legislation of most countries as a result of the formation of a system of privileges. For example, in Russia, with the adoption on August 22, 2004 of Federal Law No. 122-FZ. The rules governing monthly cash payments were introduced into the Federal Law of July 17, 1999 No. 178-FZ On State Social Assistance. Such changes in the legislation cannot be called justified, because the majority of recipients of monthly cash payments, in our opinion, are not among the poor, but, despite this, measures for state social assistance are traditionally provided for individual citizens.

It follows that monthly cash payments replaced in-kind privileges, but to consider them as compensatory privileges, in our opinion, would be a mistake. Privileges in the context of social security are considered by individual economists, that is, E.N. Khodjaev and Z. Rasulov as a means of creating favorable conditions for citizens in difficult situations: full or partial release from the performance of certain duties. [6] Compensation payments are made in order to restore the property status of the recipient. Privileges are privileges earned by previous work, and not circumstances that entail a deterioration in the financial situation of citizens, requiring compensation [see figure 2].

For monthly cash payments, the main sign of subsidies is not characteristic - the use of funds for the purposes established by the Budget Code of the Republic of Uzbekistan. It seems that it would be logical to consider and designate monthly cash payments as an allowance, moreover, in domestic legislation social assistance is defined as social allowance (social benefit), free provision of a certain amount of money to citizens at the expense of budgets of all levels.

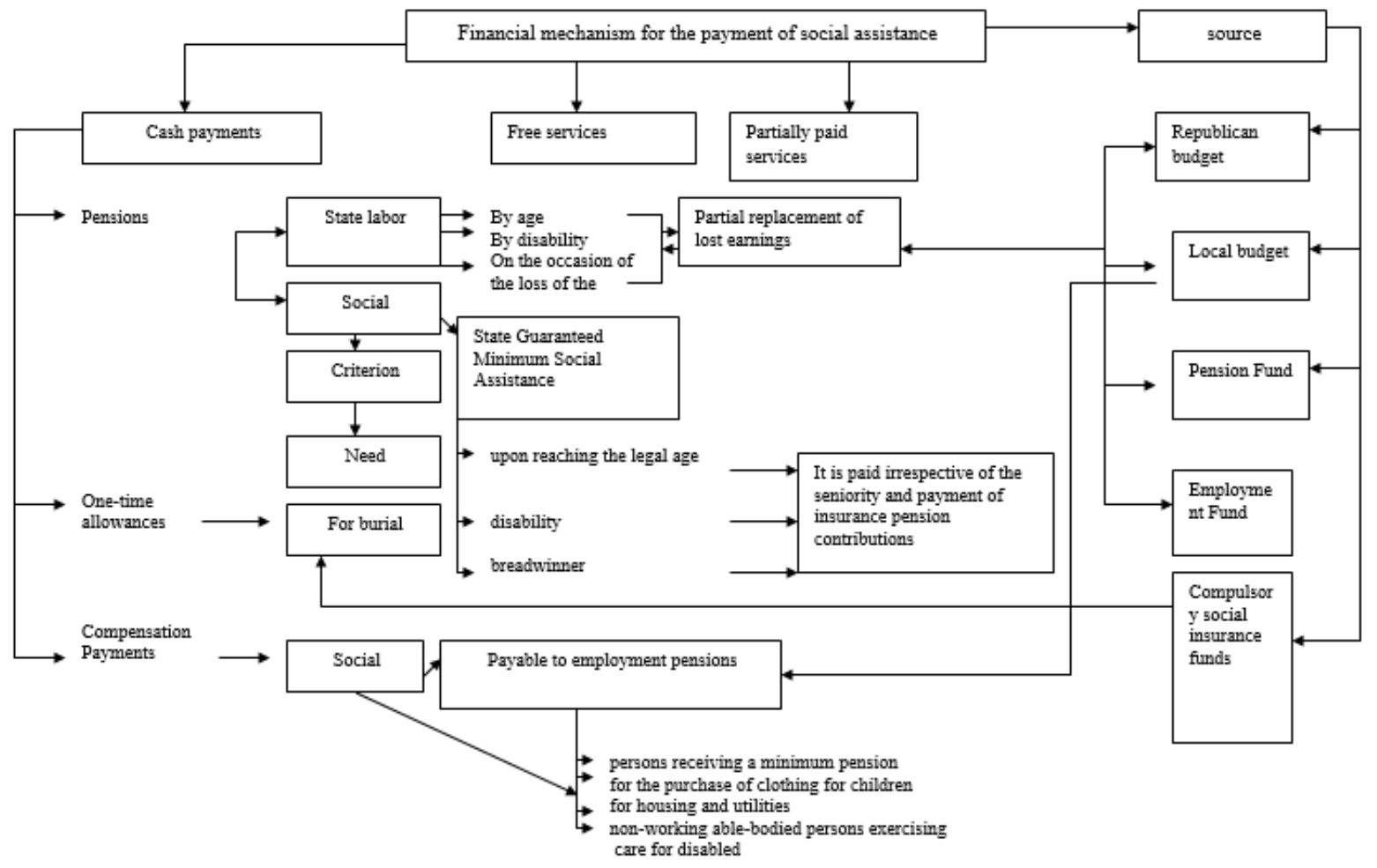




\section{Conclusion and suggestions}

One of the elements of social security that countries, where population growth faces certain problems, is looking forward to is the payment of maternal (family) capital. In the CIS countries, the Federal Law of December 29, 2006 No. 256-FZ "On Additional Measures of State Support to Families with Children" was introduced. The concept of this type of social security can be deduced from Art. 2 of the said Law. So, maternal (family) capital means of the federal budget, transferred to the budget of the Pension Fund of the Russian Federation for the implementation of additional measures of state support, providing the opportunity to improve housing conditions, education, as well as increase the level of pension provision. [8] There is currently no need to introduce such an element of social security in the Republic of Uzbekistan. This in our conditions is a costly measure. In addition, this can lead to a sharp increase in population. For our Republic, without such an event, population growth is stable, and, in our opinion, other existing elements of social security contribute to population growth.

In our opinion, such a payment - maternal (family) capital - is, although a new element of social security for Russia. But in essence, maternal (family) capital, both in content and in terms of provision, differs from other elements of social security paid both in cash and in kind (pensions, allowances, compensation payments and social services), since it can be obtained and spent only in three directions, strictly defined by law.

Along with this, it should be noted that the targeted nature of use is not the basis for considering this cash payment as a new element of social security. It is this feature that brings maternal (family) capital closer to such an element of social payments as subsidies. Adequate features are non-cash form of provision and financing of social payments from the budgets of all levels.

From the foregoing, it can be concluded that the terminology used by the legislator in the field of social security is unreasonably expanded. These various payments should not be considered as dictated by objective novelty within the framework of social security, since the nature of cash payments is sometimes hidden behind various terms. J.R. Zaynalov rightly notes that each element can exist in the system, only specializing, performing special functions necessary for the effective functioning of the entire social security system as a whole. [4] [5] The arbitrary introduction of new terms into the laws is not consistent with the internal structure of social security and prevents the formation of a systemic financial regulation of social security.

\section{References}

1. Labour Code of the Republic of Uzbekistan (enacted on April 1, 1996) -T.: Adolat, 2000. -276 Pp.

2. Право социального обеспечения: учебник/ Под ред. М.В.Филипповой. М.: Юристъ, 2006. 436 с. -170с.

3. Алиева С.С. Разграниченность компенсационных выплат. Инновацион ва рақамли иқтисодиёт шароитида хизмат кўрсатиш сохасини ривожлантириш муаммолари. Халқаро илмий-амалий конференция материаллари (VII қисм). 2020 йил 21-22 февраль.

4. Zaynalov J. Back to the essence and meaning of the term social protection. // International independent scientific journal. №14 2020 vol. 2 Pp.4-8.

5. Zaynalov J. Distinguishing features of benefits from other elements of social security. // Norwegian Journal of development of the International Science №41/2020 ISSN 3453-9875 VOL.2 Pp.3-5.;

6. Khodjaev E., Rasulov Z. Efficiency of social security resources and their part in addressingindividuals in need of social support. // International independent scientific journal. №14 2020 vol. 2 Pp.3-4.

7. Budget Code of the Republic of Uzbekistan (adopted with 26.12.2013) //Assembly of Legislation of the Republic of Uzbekistan, 2013, No. 52-I.

8. On additional measures of state support for families with children: Federal Law of the Russian Federation of December 29, 2006 No. 256-FZ//Sobr. Legislation of the Russian Federation. 2007. No. 1 (part 1), Pp 19. 